\title{
KAJIAN TERHADAP PROSES PENYELESAIAN PERKARA KEPAILITAN DAN PENUNDAAN KEWAJIBAN PEMBAYARAN UTANG DI PENGADILAN NIAGA JAKARTA PUSAT
}

\author{
Oleh: \\ Theresia Endang Ratnawati \\ Senior Legal Adviser Bank Central Asia (BCA) Jakarta
}

\begin{abstract}
Law No.4 Year 1998 is not yet accomodate the importance of corporate in the world. To soving the constraint in applying of Law No. 4 Year 1998, the government have released Law No. 37 Year 2004 that concerning Bankrupt and Postponement of Obligation To Pay Debt in the place of Law No. 4 Year 1998. in the other side, the released of Law No.37 Year 2004 not yet earned the enthusiasm of the creditors to go through bankrupt process to finishing loan that stuck from [all] his debitors. Pursuant to the research, it can be concluded that amount of the cases of bankrupt is influenced by subtantion of law that arranging bankrupt, institute performance/ commisioned functionary that handle bankrupt case and asset of recovery of the bankrupt process. Result of lowness asset recovery and process of solving the case of bankrupt which is relative long will be degraded the enthusiasm of the creditor to finish the receivable of passing bankrupt process.
\end{abstract}

Kata Kunci: Kepailitan, Asset Recovery

\section{A. PENDAHULUAN}

Hukum kepailitan sebenarnya sudah ada di Indonesia sejak tahun 1905 dengan pengaturan dalam bentuk faillisements-Verordening Staatsblaad Ta-hun 1905 No. 217 juncto Staatsblaad Tahun 1906 No.348 (FV). Namun terjadinya krisis moneter di Indonesia tahun 19971998 telah memberi dampak yang tidak menguntungkan terhadap perekonomian nasional. Untuk membantu dunia usaha agar dapat segera menyelesaikan pinjaman bermasalah, Pemerintah Republik Indonesia telah mengeluarkan Peraturan Pemerintah Pengganti Undang-undang No. 1 Tahun 1998 tentang Kepailitan yang kemudian dikukuhkan menjadi Undang-undang No. 4 Tahun 1998 tentang Kepailitan.

Diundangkannya UU No. 4 Tahun 1998 ten-tang Kepailitan telah menimbulkan harapan besar bagi dunia usaha untuk dapat segera menyelesaikan pinjaman bermasalah dengan cepat melalui proses kepailitan. Kepailitan yang semula tidak menjadi fokus publik dan tidak menarik mendadak menjadi proses penyelesaian pinjaman bermasalah yang sangat di minati oleh para pelaku usaha. Hal ini terlihat dengan adanya lonjakan jumlah permohonan kepailitan di Pengadilan Niaga Jakarta Pusat menjadi 100 perkara kepailitan yang masuk dalam tahun 1999.

Pada awalnya dunia usaha memang sangat berharap Pengadilan Niaga mampu menyelesaikan perkara yang masuk dengan cepat, transparan, dan adil. Namun dalam perkembangannya Pengadilan Niaga menemui banyak hambatan dalam menyelesaikan tugasnya sehingga hasil kinerjanya menjadi tidak maksimal. Kondisi ini mengecewakan para pelaku usaha sehingga mereka menjadi kurang berminat menempuh proses kepailitan untuk menyelesaikan kemelut pinjaman bermasalah yang dihadapinya.

Mengingat UU No. 4 Tahun 1998 dirasa belum dapat mengakomodir kepentingan dunia usaha dan untuk mengatasi kendala dalam praktik penerapan UU No. 4 Tahun 1998 maka dikeluarkan UU No. 37 Tahun 2004 tentang Kepailitan dan Penundaan Kewajiban Pembayaran Utang sebagai pengganti UU No. 4 Tahun 1998. 
Untuk mengetahui perkembangan penyelesaian perkara kepailitan di Pengadilan Niaga selama periode berlakunya UU No.4 Tahun 1998 dan UU No.37 Tahun 2004, penulis telah melakukan penelitian di Pengadilan Niaga Jakarta Pusat. Dari data perkara yang diperoleh, penulis melakukan kajian untuk mencari penyebab naik turunnya jumlah perkara selama periode yang diteliti dan untuk mengetahui kendala-kendala yang timbul dalam proses penyelesaian perkara kepailitan. Pelaku usaha tentu berharap proses kepailitan dapat membantu mempercepat hasil penyelesaian hutang piutang dengan hasil asset recovery yang maksimal. Penulis berharap makalah ini akan dapat memberikan sumbangan pemikiran untuk dapat mengupayakan pemberdayakan hukum kepailitan agar dapat mengatasi permasalahan dalam penyelesaian utang piutang melalui proses kepailitan.

\section{B. Penyelesaian Perkara Kepailitan dan Pe- nundaan Pembayaran Utang di Pengadilan Niaga Jakarta Pusat}

\section{Hasil Penelitian}

Dari hasil penelitian di Pengadilan Niaga Jakarta Pusat, penulis mendapatkan data-data perkara yang dapat diklasifikasikan menjadi 3 kelompok data yakni :

Tabel 1

Data Perkara Kepailitan Periode 1998-2006

\begin{tabular}{|l|r|r|r|r|r|r|r|r|r|}
\hline $\begin{array}{l}\text { Perkara kepailitan di } \\
\text { Pengadilan Niaga }\end{array}$ & 1998 & 1999 & 2000 & 2001 & 2002 & 2003 & 2004 & 2005 & 2006 \\
\hline Perkara Masuk & 31 & 100 & 84 & 61 & 39 & 38 & 52 & 44 & 36 \\
\hline Putusan dikabulkan & 6 & 35 & 32 & 21 & 9 & 9 & 16 & 18 & 18 \\
\hline Putusan ditolak & 3 & 34 & 15 & 28 & 15 & 12 & 20 & 14 & 8 \\
\hline $\begin{array}{l}\text { Putusan tidak dapat } \\
\text { diterima }\end{array}$ & 2 & 9 & 3 & 3 & 1 & 3 & 1 & 3 & 1 \\
\hline Dicabut & 3 & 14 & 25 & 9 & 9 & 9 & 7 & 8 & 5 \\
\hline Digugurkan & 4 & 3 & 1 & 0 & 0 & 0 & 0 & 0 & 0 \\
\hline Damai & 2 & 5 & 9 & 0 & 8 & 1 & 4 & 1 & 0 \\
\hline $\begin{array}{l}\text { Ditunda karena ada } \\
\text { permohonan PKPU }\end{array}$ & 0 & 8 & 6 & 5 & 0 & 0 & 0 & 0 & 2 \\
\hline Sisa perkara & 11 & 11 & 10 & 5 & 2 & 6 & 10 & 10 & 12 \\
\hline
\end{tabular}

Grafik 1

Data Penyelesaian Perkara Kepailitan Di Pengadilan Niaga Jakarta Pusat Tahun 1998 Sampai Dengan Tahun 2006

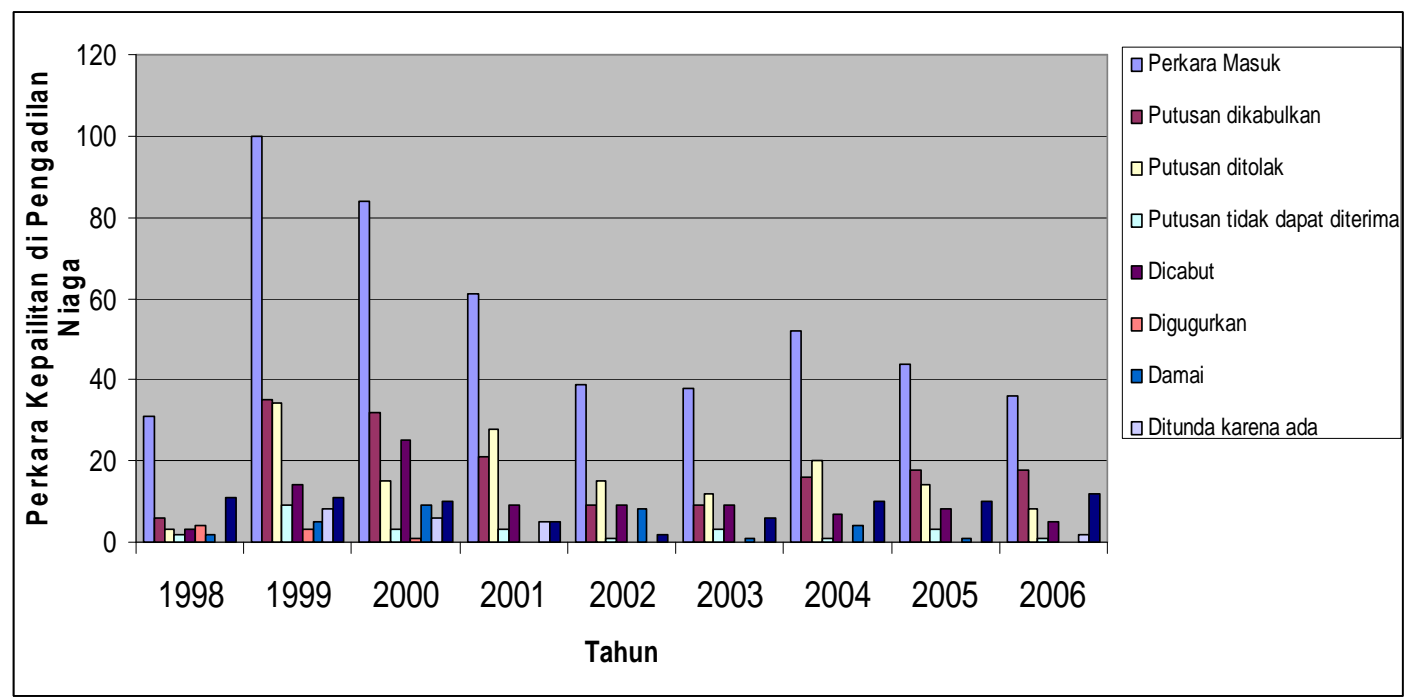


146 Jurnal Dinamika Hukum

Vol. 9 No. 2 Mei 2009

Tabel 2

Data Perkara Permohonan Penundaan Kewajiban Pembayaran Utang Di Pengadilan Niaga Jakarta Pusat Periode Tahun 1998 Sampai Dengan Tahun 2006

\begin{tabular}{|l|r|r|r|r|r|r|r|r|r|}
\hline PKPU TIDAK MURNI & 1998 & 1999 & 2000 & 2001 & 2002 & 2003 & 2004 & 2005 & 2006 \\
\hline Perkara PKPU Masuk & 10 & 15 & 21 & 8 & 5 & 3 & 4 & 3 & 7 \\
\hline Putusan dikabulkan (pailit) & 2 & 5 & 11 & 0 & 0 & 0 & 1 & 0 & 0 \\
\hline Putusan ditolak & 0 & 0 & 0 & 0 & 0 & 0 & 0 & 0 & 0 \\
\hline Putusan tidak dapat diterima & 0 & 0 & 0 & 0 & 0 & 0 & 0 & 0 & 0 \\
\hline Dicabut & 0 & 4 & 0 & 0 & 1 & 1 & 0 & 1 & 1 \\
\hline Digugurkan & 2 & 0 & 0 & 0 & 0 & 0 & 0 & 0 & 0 \\
\hline Damai & 0 & 8 & 11 & 4 & 4 & 1 & 1 & 1 & 0 \\
\hline Putusan PKPU tetap & & & & & & 1 & 1 & 1 & 0 \\
\hline Putusan PKPU sementara & & & & & & 0 & 0 & 0 & 1 \\
\hline Sisa perkara & 6 & 4 & 2 & 7 & 0 & 1 & 1 & 1 & 6 \\
\hline
\end{tabular}

Grafik 2

Grafik Penyelesaian Perkara Penundaan Kewajiban Pembayaran Utang Tidak Murni Di Pengadilan Niaga Jakarta Pusat Tahun 1998 Sampai Dengan Tahun 2006

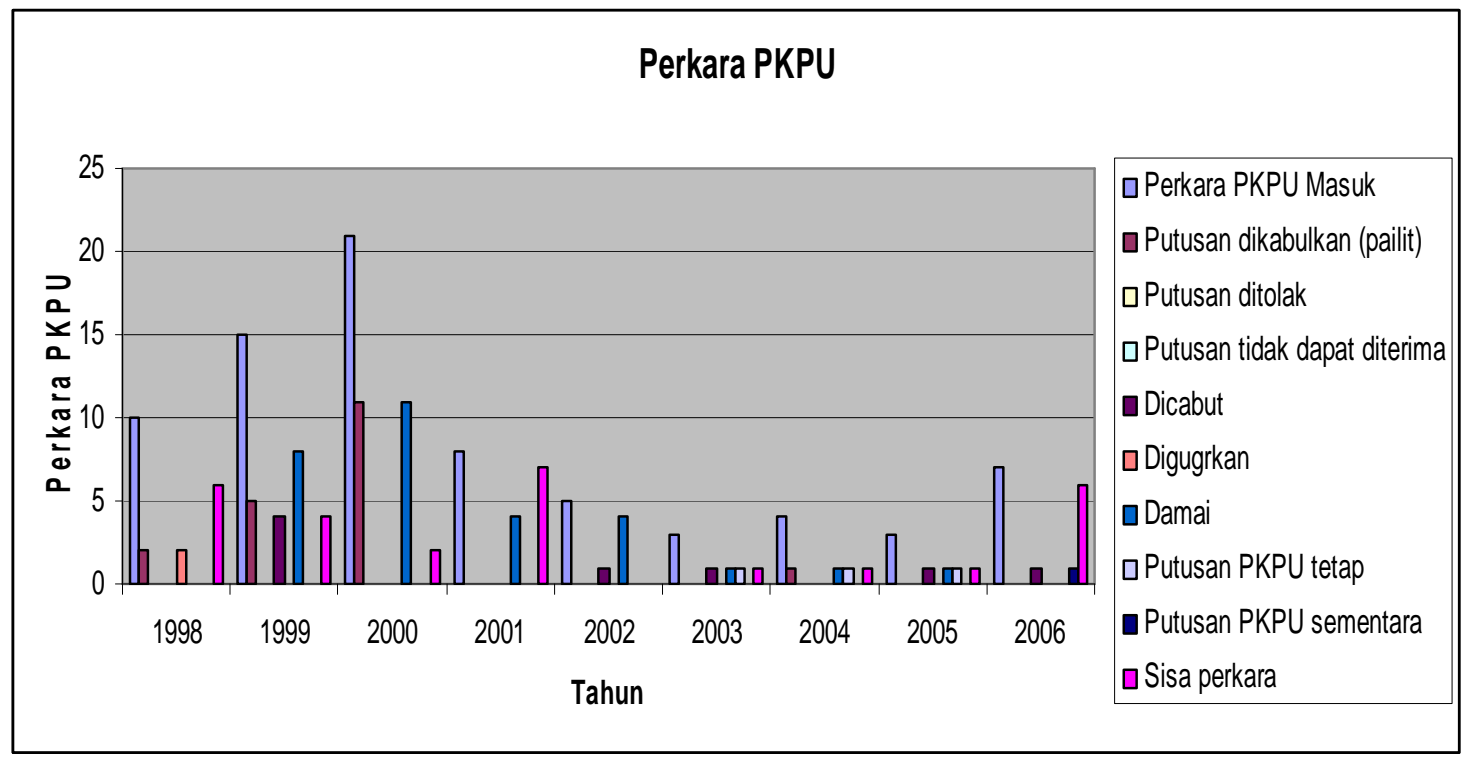

Tabel 3

Data Perkara Permohonan Penundaan Kewajiban Pembayaran Utang Murni Periode Tahun 1998 Sampai Dengan Tahun 2006

\begin{tabular}{|l|c|c|c|c|c|c|c|c|c|}
\hline \multicolumn{1}{|c|}{ PKPU MURNI } & 1998 & 1999 & 2000 & 2001 & 2002 & 2003 & 2004 & 2005 & 2006 \\
\hline Perkara PKPU Masuk & & & 5 & 6 & 7 & 2 & 2 & 3 & 0 \\
\hline Putusan dikabulkan (pailit) & & & & 1 & & & & & 0 \\
\hline Putusan ditolak & & & & & & & & & 0 \\
\hline Putusan tidak dapat diterima & & & & & & 1 & 1 & 1 & 0 \\
\hline Dicabut & & & & & 2 & 0 & 0 & 0 & 0 \\
\hline Digugurkan & & & & & 0 & & & & 0 \\
\hline Damai & & & 4 & 3 & 4 & 1 & 1 & 2 & 0 \\
\hline Putusan PKPU tetap & & & & & & & & & \\
\hline Putusan PKPU sementara & & & & & & & & & \\
\hline Sisa perkara & & & 1 & 3 & 4 & 4 & 4 & 0 & 0 \\
\hline
\end{tabular}




\section{Grafik 3}

Grafik Penyelesaian Perkara Penundaan Kewajiban Pembayaran Utang Murni Di Pengadilan Niaga Jakarta Pusat Tahun 1998 Sampai Dengan Tahun 2006

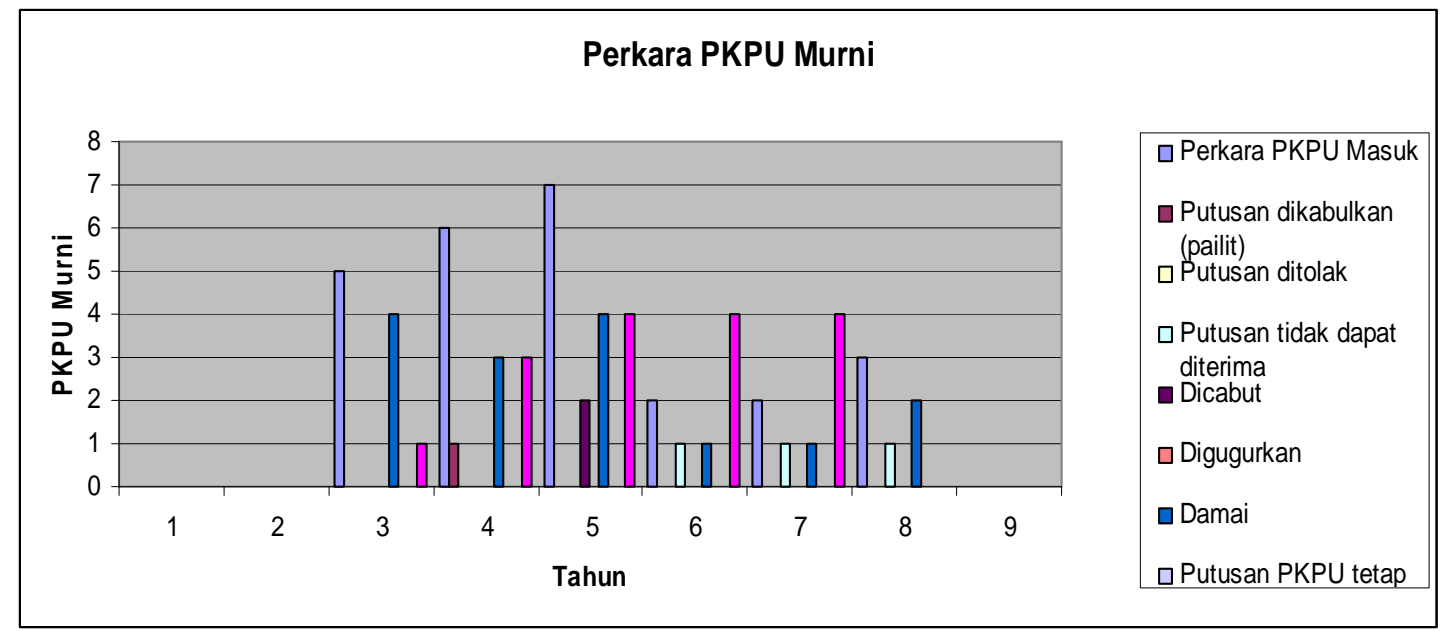

\section{Pembahasan}

a. Kajian terhadap Perkembangan Penyelesaian Perkara Kepailitan dan Penundaan Kewajiban Pembayaran Utang

Kajian terhadap penyelesaian perkara kepailitan dan Penundaan Kewajiban Pembayaran Utang dalam makalah ini akan dilakukan terhadap ketiga aspek dari legal system terkait dengan proses kepailitan. Legal system menurut Lawrence M. Friedman adalah composed of structure, substance and cultural. Sedangkan L.A. Hart juga menyatakan bahwa $A$ Legal system is the union of "primary rules" (norms of behavior) and "secondary rules" (norms about those norms-how to decide whether they are valid, how to enforce them, etc). ${ }^{1}$

Pada 2002 Komisi Hukum Nasional bekerja sama dengan Universitas Andalas telah melakukan survey terhadap hakim dan pengacara mengenai penyebab turunnya jumlah perkara niaga di Pengadilan Niaga. Hasil penelitian tersebut adalah sebagai berikut :

\footnotetext{
1 Lawrence M. Friedman, 1995, The Legal System, A Social Science Perspective, New York, hlm. 14.
}

Tabel 4

Penyebab Turunya Jumlah Perkara Niaga di Pengadilan Niaga ${ }^{2}$

\begin{tabular}{|c|c|c|}
\hline Faktor Penyebab & Hakim & $\begin{array}{l}\text { Pengacara/ } \\
\text { Konsltn Hk }\end{array}$ \\
\hline $\begin{array}{l}\text { Tidak puas atas hasil } \\
\text { putusan }\end{array}$ & 1 & 5 \\
\hline $\begin{array}{l}\text { Hasil putusan tidak men- } \\
\text { cerminkan asas keadilan }\end{array}$ & 1 & 5 \\
\hline $\begin{array}{l}\text { Tidak ada informasi me- } \\
\text { ngenai perluasan yuris-diksi } \\
\text { pengadilan Niaga ke bidang } \\
\text { HAKi }\end{array}$ & 0 & 4 \\
\hline Prosedur yang berbelit-belit & 1 & 2 \\
\hline $\begin{array}{l}\text { Kuasa hukum/advokat lebih } \\
\text { memilih Pengadilan Negeri }\end{array}$ & 0 & 3 \\
\hline $\begin{array}{l}\text { Lainnya (kemungkinan di- } \\
\text { pilih ADR) }\end{array}$ & 3 & 0 \\
\hline
\end{tabular}

Sumber : Diolah dari hasil survey penelitian mengenai Pengadilan Niaga, kerjasama Komisi Hukum Nasional dan Universitas Andalas, 2006

\section{Grafik 4}

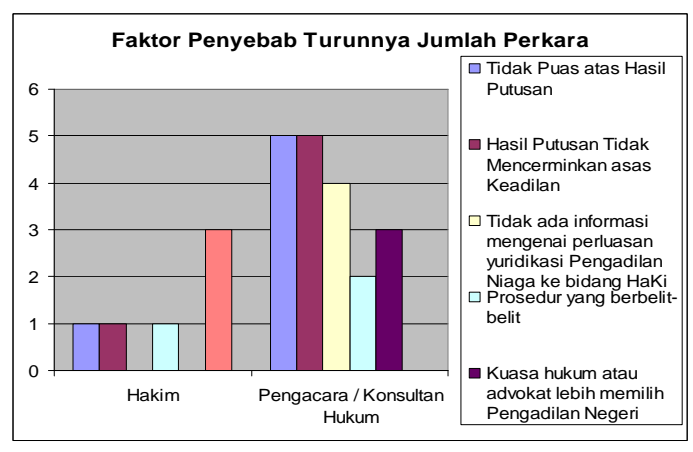

2 Direktorat Hukum dan Hak Asasi Manusia, Eksistensi Pengadilan Niaga Dan Perkembangannya Dalam Era Globalisasi, bappenas.go.id, hlm.11. 
Di samping penyebab tersebut di atas didapatkan data dari beberapa narasumber bahwa tingkat pemulihan aset (asset recovery) atas penyelesaian perkara kepailitan sangat rendah. Padahal asset recovery merupakan indikator dasar berhasil atau tidaknya hukum kepailitan di sebuah negara.

Hasil penelitian terhadap asset recovery dan jangka waktu penyelesaian proses kepailitan yang dilakukan oleh beberapa lembaga menunjukkan data sebagai berikut:

1) Data Hasil Penelitian Pusat Peng-kajian Hukum (PPH): ${ }^{3}$

a) Rata-rata prosentase asset recovery dalam kepailitan berdasarkan data dari kurator yang menjadi responden.

(1) Aset Recovery yang diterima Kreditur Konkuren

- $18,17 \%$ kasus kepailitan yang berakhir dengan pembagian penutup dan likuidasi aset.

- $19,71 \%$ kasus kepailitan yang berakhir dengan penyelesaian di luar pemberesan, pemberesan ma sih berjalan dan atau kepailitan yang berakhir dengan pencabutan kepailitan karena aset tidak cukup.

(2) Asset Recovery yang diterima Kreditur Separatis :

Meskipun kreditur separatis memiliki agunan berupa aset tapi dari hasil penelitian asset recovery yang diperoleh hanya $23,35 \%$

b) Faktor penghambat yang menyebabkan rendahnya tingkat aset recovery adalah:

(1) kurangnya transparansi dan akuntabilitas dalam proses kepailitan

(2) kurangnya profesionalisme, pemahaman dan kerjasama dari para pihak antar sektoral.

(3) sulitnya melakukan pelacakan dan penguasaan aset

(4) permasalahan dalam alokasi dan pendistribusian harta pailit.

3 Di sarikan dari makalah Temu Karya Asset Recovery dalam Kepailitan, PPH Newsletter No. 69 Juni 2007, hlm. 33-34.
(5) kurang digunakannya instrumen atau upaya hukum lainnya, dan

(6) ketidakjelasan dari beberapa ketentuan hukum dan perundang-undangan.

c) Jangka waktu proses kepailitan

(1) Rata-rata jangka waktu proses kepailitan sampai dengan adanya pembagian penutup adalah 37,25 bulan atau 3 tahun 1 bulan.

(2) Rata-rata jangka waktu proses kepailitan sampai kepailitan diangkat karena tidak ada aset 10 bulan.

(3) Rata-rata jangka waktu proses kepailitan sampai dengan perdamaian 11 bulan.

2) World Bank dalam surveinya bertajuk Doing Business 2006 menempatkan Indonesia sebagai negara dengan tingkat recovery rate hanya $11,8 \%$. Sedang waktu pemberesan rata-rata mencapai 5,5 tahun, tingkat biaya kepailitan $18 \%$ dari total budel/harta pailit. ${ }^{4}$ Walau belum jelas metodologi yang digunakan dalam survei, namun data tersebut merupakan lampu kuning bagi masyarakat internasional terhadap kinerja hukum kepailitan di Indonesia.

Dari data diatas penulis melakukan kajian terhadap legal system yang terkait dengan proses Kepailitan dan Penundaan Kewajiban Pembayaran Utang ("PKPU").

\section{b. Kajian terhadap Substansi Hukum yang Dipakai Sebagai Dasar Penyelesaian Perkara Kepailitan Dan PKPU \\ Diundangkannya UU No. 4 Tahun 1998} tentang Kepailitan telah memberikan pengaturan yang lebih menarik bagi pelaku usaha. Paling tidak ada 7 substansi pokok pembaharuan ketentuan kepailitan yang diatur dalam Faillisments Verordening Staatsblad 1905:217 juncto Staatsblad 1906:348 yakni: ${ }^{5}$

1) Penyempurnaan syarat-syarat dan prosedur kepailitan, termasuk di dalamnya pemberi-

\footnotetext{
${ }^{4}$ Rendah, Pemulihan Aset Dalam Kepailitan, hukumonline.com, tgl 19 November 2007, hlm. 1

5 Aria Suyudi, Eryanto Nugroho, dan Herni Sri Nurbayanti, 2004, Kepailitan di Negeri Pailit, Jakarta: Pusat Studi Hukum dan Kebijakan Indonesia, hlm. 26-27
} 
an kerangka waktu yang pasti bagi pemberian putusan kepailitan.

2) Penyempurnaan pengaturan yang bersifat penambahan ketentuan tentang tindakan sementara yang dapat diambil pihak-pihak yang bersangkutan, khususnya kreditur, atas kekayaan debitur sebelum adanya putusan kepailitan.

3) Peneguhan fungsi kurator dan penyempurnaan yang memungkinkan berfungsinya jasa-jasa tersebut disamping Balai Harta Peninggalan.

4) Penegasan tentang upaya hukum yang dapat diambil terhadap putusan kepailitan yakni permohonan kasasi kepada Mahkamah Agung.

5) Dalam rangka penyempurnaan dan kelancaran proses kepailitan dan pengamanan berbagai kepentingan secara adil, juga ditegaskan adanya mekanisme penangguhan pelaksana-an hak diantara kreditur yang me-megang hak tanggungan, gadai atau agunan lainnya. Diatur pula ketentuan mengenai status hukum atas perikatanperikatan yang telah dibuat debitur sebelum adanya putusan kepailitan.

6) Penyempurnaan dilakukan pula terhadap ketentuan tentang penundaan kewajiban pembayaran sebagaimana telah diatur dalam Bab Kedua Undang-Udang Kepailitan.

7) Penegasan dan pembentukan peradilan khusus yang akan menyelesai-kan masalah kepailitan secara umum.

Namun dalam pelaksanaannya, UU No. 4 Tahun 1998 tentang Kepailitan (UUK Lama) ternyata mempunyai beberapa kelemahan antara lain :

1) Dalam UUK lama terdapat peng-aturan yang kurang tegas sehingga dalam praktik timbul interpretasi yang bermacam-macam, misalnya tidak ada pengertian yang tegas terhadap utang sehingga sering ditafsirkan berbeda oleh hakim Pengadilan Niaga dan Hakim Mahkamah Agung yang memeriksa kasus yang sama. Adanya penafsiran yang berbeda tersebut telah menimbulkan ketidak konsistenan dalam putusan hakim da-lam suatu kasus kepailitan sehingga menimbulkan ketidakpastian hukum.
2) Adanya batasan waktu 30 hari yang di berikan UUK Lama untuk memberikan putusan kepailitan justru sulit dilaksanakan dalam praktik karena terlalu cepat. Jika dipaksakan putusan dalam jangka waktu 30 hari, hakim hanya mendasarkan putusannya pada pembuktian sederhana sekedar untuk memenuhi persyaratan dinyatakan pailit sehingga sering menimbulkan ketidakadilan bagi masyarakat sebagai contoh saat perusahaan asuransi manulife dipailitkan.

Kelemahan-kelemahan tersebut te-lah mendorong keluarnya Undang-undang No.37 Tahun 2004 (UUK Baru). Namun demikian ternyata dari hasil penelitian menunjukkan jumlah perkara kepailitan di Pengadilan Niaga, untuk tahun 2004 tidak menunjukkan kenaikan yang signifikan, sedangkan tahun 2005 dan 2006 jumlah perkara justru menurun.

Dari beberapa nara sumber didapatkan informasi bahwa penyebab utama menurunnya jumlah perkara kepailitan lebih disebabkan rendahnya tingkat asset recovery yang diterima kreditur. Proses penyelesaian hutang piutang melalui kepailitan menjadi tidak menarik bagi kreditur. Namun tentunya perlu dilakukan penelitian lebih lanjut apakah menurunnya tingkat asset reco-very dalam proses kepailitan karena ada kelemahan dari sisi substansi hukum yang mengatur tentang kepailitan saat ini.

Menurut Denny Azani yang berprofesi sebagai advokat sekaligus kurator, salah satu kendala penyelamatan aset debitur yang di pailitkan adalah kurangnya kerjasama antara perbankan dengan kurator terutama terkait dengan pemblokiran rekening debitur pailit. Alasan yang didengungkan adalah adanya ketentuan rahasia bank.

Menurut pendapat penulis, apa yang dikeluhkan oleh Denny Azani tidak perlu terjadi karena permintaan pemblokiran dari kurator dan atau pengungkapan data nasabah penyimpan dan simpanannya kepada kurator yang berwenang mewakili nasabah pailit tidak melanggar ketentuan rahasia bank. Sesuai ketentuan hukum yang berlaku, kurator berwenang bertindak mewakili nasabah pailit. Oleh karena itu perlu dilakukan edukasi kepada 
perbankan agar tidak menghambat proses pemblokiran rekening maupun permintaan data nasa-bah penyimpan dan simpanan nasabah pailit selama pihak kurator dapat menunjukkan:

1) Putusan Kepailitan Pengadilan Niaga atas nasabah yang bersangkutan.

2) Bukti pengangkatan kurator dan ha-kim pengawas yang diberi wewenang untuk melakukan pemberesan ter-hadap harta nasabah pailit.

Dengan demikian kurator dapat segera mengamankan harta pailit.

\section{c. Kajian terhadap Struktur Hukum yang Terlibat dalam Penyelesaian Perkara Kepailitan \\ Lembaga yang mempunyai peran funda-} mental dalam penyelesaian proses kepailitan adalah Pengadilan Niaga. Pe-ngadilan Niaga telah ditunjuk secara khusus untuk menangani perkara kepailitan. Pembentukan Pengadilan Niaga merupakan deferensiasi atas Peradilan Umum yang dimungkinkan pembentukannya berdasarkan UU No. 14 Tahun 1970 tentang Pokok-Pokok Kekuasaan Kehakiman. Dalam praktik penyelesaian proses kepailitan sering di temui inkonsistensi antara putusan hakim Pengadilan Niaga dengan hakim Mahkamah Agung sehingga menimbulkan ketidakpastian hukum. Kadang dalam praktik Pengadilan Niaga dengan berbagai alasan telah menolak melakukan gijzelling (Lembaga Paksa) terhadap debitur pailit sehingga para pencari keadilan semakin tidak percaya bahwa status pailit debitur akan membuat kreditur lebih mudah meminta pelunasan tagihannya dari aset debitor yang dipailitkan. Alasan yang dikemukakan oleh Pengadilan Niaga adalah perangkat hukum untuk pelaksanaan gijzelling masih belum jelas dan pasti. ${ }^{6}$

Dalam praktik juga ada beberapa kurator yang kurang maksimal dalam melakukan pemberesan boedel pailit karena kurang memiliki pengetahuan dan pengalaman dalam pemberesan harta pailit.

\footnotetext{
6 Direktorat Hukum dan Hak Asasi Manusia, Eksistensi Pengadilan Niaga Dan Perkembangan-nya Dalam Era Globalisasi, bappenas.go.id, hlm. 6 dan 7
}

\section{d. Kajian terhadap Budaya Hukum dalam Penyelesaian Kepailitan}

Dalam perkara kepailitan, terutama saat verifikasi jumlah hutang dapat muncul kreditur fiktif. Jika kreditur fiktif tersebut dapat lolos dalam proses verifikasi tentunya akan menyebabkan tingkat asset recovery bagi kreditur yang sebenarnya menjadi lebih kecil. Oleh karena itu perlu dilakukan standar verifikasi kreditur yang lebih ketat agar tidak disalahgunakan oleh debitur pailit untuk menciptakan kreditur fiktif. Dalam praktik juga banyak debitur yang beritikad buruk yang dengan sengaja mengalihkan hartanya sebelum kurator sempat mengamankan harta pailit. Oleh karena itu kurator harus dengan segera menjalankan tugasnya dalam mengamankan harta pailit, mengingat actio paulina tidak mudah diterapkan karena kesulitan dalam pembuktian.

\section{Penutup}

1. Simpulan

Dari uraian diatas dapat disimpulkan sebagai berikut:

a. Berdasarkan data jumlah perkara yang masuk ke Pengadilan Niaga Jakarta Pusat dapat diketahui :

1) Jumlah perkara kepailitan mengalami peningkatan yang signifikan pada tahun 1999-2000. Peningkatan jumlah ini terjadi se-telah berlakunya UU No. 4 Tahun 1998 tentang Kepailitan. Pelaku usaha sangat berminat menempuh jalur kepailitan agar dapat menyelesaikan permasalahan hutang piutang yang dialaminya dengan lebih cepat dan harapan akan mendapatkan hasil yang maksimal.

2) Jumlah perkara kepailitan tahun 20012003 mengalami penurunan. Nampaknya pelaku usaha mulai merasa kecewa menempuh proses kepailitan karena rendahnya tingkat asset recovery yang diterima dari hasil proses pemberesan harta pailit. Di samping itu kekecewaan pelaku usaha juga muncul karena ada beberapa ketentuan UU No. 4 Tahun 1998 yang kurang tegas seperti tidak jelasnya pengertian 
hutang. Hal ini menimbulkan perbedaan persepsi dari hakim yang menangani perkara sehingga sering menghasilkan putusan yang tidak konsisten.

3) Jumlah perkara kepailitan pada 2004 menunjukkan kenaikan, namun jumlah perkara tersebut mengalami penurunan pada 2005-2006. Nampaknya keluarnya UU No. 37 Tahun 2004 yang telah menggantikan UU No. 4 Tahun 1998 belum mampu menarik minat pelaku usaha untuk menempuh proses kepailitan selama tingkat asset recovery masih tetap rendah.

4) Jumlah perkara penundaan kewajiban pembayaran hutang baik yang tidak murni maupun yang murni selama periode 19982006 hanya berkisar 0-21 perkara dalam satu tahun. Dalam praktik kreditur dan debitur lebih memilih melakukan restrukturisasi hutang secara bilateral tanpa melibatkan Pengadilan Niaga.

b. Dari hasil penelitian beberapa lem-baga, penyebab utama menurunnya perkara kepailitan adalah :

1) Tingkat asset recovery proses kepailitan yang sangat rendah. Kasus kepailitan yang berakhir dengan pembagian penutup dan likuidasi aset, asset recovery bagi kreditur konkuren hanya $18,17 \%$, sedangkan bagi kreditur separatis adalah $23,25 \%$.

2) jangka waktu pemberesan harta pailit tergolong lama, untuk proses kepailitan sampai dengan pembagian penutup di butuhkan waktu 37,25 bulan.

c. Dari perspektif kreditur, tingkat re-covery merupakan indikator berhasil atau tidaknya proses kepailitan. Jika asset recovery rendah, kreditur merasa hanya menang diatas kertas saja sehingga menyebabkan mereka tidak berminat menempuh proses kepailitan untuk menyelesaikan permasalahan hutang piutangnya.

\section{Saran}

Dari data diatas nampak bahwa pemberesan harta pailit merupakan faktor yang fundamental dalam proses kepailitan. Kreditur pasti ingin memperoleh asset recovery yang maksimal. Oleh karena itu penulis menyarankan dilakukan penelitian yang lebih mendalam tentang bagaimana dapat memberdayakan hukum untuk mendukung peningkatan asset recovery sebagaimana diharapkan pelaku usaha. Hal-hal yang perlu diteliti antara lain:

a. Apakah substansi hukum terkait dengan pengaturan pemberesan harta pailit sudah dapat men-dukung peningkatan asset recovery dalam kepailitan?, dan Substansi hukum mana saja yang menjadi kendala sehingga dapat menghambat pemberesan harta pailit?

b. Apakah struktur hukum yang ada telah mendukung kelancaran proses pemberesan harta pailit? Apakah kurator, hakim pengawas, dan pihak lain terkait telah memiliki kompetensi yang dibutuhkan untuk melakukan pemberesan harta dengan adil, cepat, dan transparan sehingga mendapatkan hasil maksimal?

c. Bagaimana memberdayakan budaya hukum dari semua pihak yang terkait dengan proses ke-pailitan agar senantiasa menunjukkan sikap bekerjasama dengan itikad baik untuk dapat mengatasi permasalahan dalam proses kepailitan pada umumnya dan pemberesan harta pailit pada khususnya.

Hasil penelitian ini dapat dipakai sebagai bahan untuk melakukan pemberdayaan substansi, struktur, dan budaya hukum untuk mendukung peningkatan asset recovery dalam proses kepailitan. Kondisi ini diharapkan dapat memulihkan kepercayaan para pelaku usaha terhadap proses kepailitan di Indonesia.

\section{Daftar Pustaka}

Direktorat Hukum dan HakAsasi Manusia. Eksistensi Pengadilan Niaga dan Perkembangannya Dalam Era Globalisasi. bappenas.go.id;

Hartini, Rahayu. 2007. Hukum Kepailitan, Edisi Revisi. Malang: UPT Penerbitan Univ. Muhammadiyah;

Makalah Temu Karya Asset Recovery dalam Kepailitan, PPh Newsletter No. 69, bulan Juni 2007, Jakarta: Yayasan Pusat Pengkajian Hukum; 
152 Jurnal Dinamika Hukum

Vol. 9 No. 2 Mei 2009

Hukumonline.com, Rendah pemulihan aset dalam kepailitan, artikel, tanggal 19 November 2007;

Sjahdeini, Sutan Remy. 2004. Hukum Kepailitan. Edisi Revisi. Jakarta: PT. Pustaka Utama Grafiti;

Suyudi, Aria, Eryanto Nugroho, Herni Sri Nurbayati. 2004. Kepailitan di Negeri Pailit, Jakarta: Pusat Studi Hukum dan Kebijakan Indonesia;

Wignjosumarto, Parwoto. 2003. Hukum Kepailitan, Selayang Pandang (Himpunan Makalah). Jakarta: PT Tatanusa; 